\title{
Current Situation of Teaching and Learning in the Subject of Social Studies (Pakistan Studies) at Secondary School Level
}

\author{
Dr. Abida Nasreen \\ Assistant Professor, Institute of Education and Research, University of the Punjab, Lahore, Pakistan \\ E-mail: abidanasreen@gmail.com \\ Ms. Anjum Naz \\ Lecturer, Department of Education, University of Sargodha, Sargodha, Pakistan \\ E-mail: anjumnaz@hotmail.com \\ Dr. Riffat-Un-Nisa Awan \\ Assistant Professor, Department of Education, University of Sargodha Sargodha, Pakistan \\ E-mail: riffatawan@uos.edu.pk
}

Received: December 3, 2010

Accepted: January 19, 2011

doi:10.5539/ass.v7n6p113

\begin{abstract}
Social studies promote civic competence in the students and disciplinary knowledge of social studies is drawn primarily from the social science disciplines i.e., anthropology, economics, geography, history, political science, psychology etc. Effectiveness of teaching depends on teachers' knowledge, attitudes, beliefs and skills to develop close contact with students. Present study was undertaken to find out the current situation of teaching and learning of social studies at the secondary school level. Data was solicited from thirty teachers and hundred students of secondary school level (grade 9-10) through structured interviews. The information collected through interviews was organized under different themes. Response averages were calculated to support the narrative data. Narrative data was further reported as it was described by the interviewees. Teachers' and students' views were found contradictory on some points that raised some serious questions about important areas of concern in teaching and learning of social studies at secondary schools in Lahore, Pakistan. School administrators should take certain measures to facilitate and guide teachers to overcome their deficiencies with good supervision, provision of facilities, encouragement, timely feedback to teachers and direct and regular interaction with students on reported areas of concern.
\end{abstract}

Keywords: Social studies, Secondary schools, Parents attitude, Lesson planning

\section{Introduction}

Education is of vital important for the development of every individual in the human society. It enables him to observe and examine various aspects of life critically and utilize them for the not only to the personal promotion but also for the development of society. Education helps a man to become valuable citizen.

In our society it is seen that the profession of teaching is mostly the second choice of teachers. As a result the standard of education is gradually falling because of the lack of interest on the part of teachers. However, teaching can be made more effective by capable and skilled and qualified teachers, practicing modern teaching methods, using audio-video Aid, implement more experimental/practical work and bringing up-to-date books in school libraries. According to Arends (2004) teachers should help students to construct their own knowledge and involve them in their own learning. Further, Blair (1988) expresses his views on need of seeking advice by the teachers from the other professionals and said that a professional teacher is a member of a team that acknowledges the expertise of other professionals and looks for advice or help when needed. This is necessary to become successful teacher. According to Cullingford (1995), there are two characteristics of unsuccessful teachers: one is a lack of self awareness, for example they do not know, whether they are doing right or wrong. Secondly, they can not bear any criticism, no matter how constructive it is. The importance of teacher training 
can not be ignored. Dahama and Bhatnagar (1997) said that professional training educates a person to become more fitted, qualified and proficient in doing some job. There should be proper planning for teachers' training programs as Panda and Tewari (1997) highlighted the importance of training by saying that training is the reorientation of higher education to help prospective teachers to understand the environment of the students and how to modify that.

The content areas of social studies relates directly to the organization and progress of human society and to man as a member of social groups. Schools are assumed to prepare students citizenship to participate energetically and responsibly in a democratic society. So, the system of education needs to strengthen social and national integration, develop intellectual originality, and struggle to build national character. It is the task of educational system to help students to develop an insight into human interaction, social values and attitudes and enable them to get rid of what is undesirable. As far as the definitions of social studies are concerned, some are given below:

According to Michaels, (1979) "The social studies is concerned with man and his interaction with his social and physical environment, they deal with human relationships. The central function of the social studies is identical with the central purpose of development of citizenship."

"The social studies as the name suggests, are studies of society and their chief aim to help pupils to understand the word in which they have to live" (Forrester, 1979: P3) Social studies according to Barth, (1980) is the integration of experienced and knowledge concerning human relationships for the purpose of citizenship education. In America National council for social studies (NCSS), has made curriculum standards for social studies. The formal definition given by them is given below:

"Social studies is the integrated study of the social sciences and humanities to promote civic competence. Within the school program social studies provides coordinated, systematic study drawing upon such disciplines as anthropology, archeology, economics, geography, history, law, philosophy, political sciences, psychology, religion and sociology, as well as appropriate content from the humanities, mathematics and natural sciences. The primary purpose of social studies is to help young people develop the ability to make informed and reasoned decisions for the public good as citizens of a culturally diverse, democratic society in an interdependence world." (P3)

Many countries are now realizing the importance of social studies education for their success and development because Social studies provide for a variety of experiences for the well balanced student's learning. So the program has to be comprehensive enough to cover all the problems and situations that arise in daily living.

According to Aggarwal (1983), the social studies contain the following ideas:

1. Geography: to exist, man must utilize natural resources.

2. History: the life of man has been and in influenced by change.

3. Economics: Productive resources are scarce and human wants are limited.

4. Political Science: Man seeks to establish and maintain a public authority through which to govern and be governed.

5. Psychology: Man's behavior is purposive and goal oriented.

6. Sociology: Man is a social being.

7. Anthropology: Man is man, yet everywhere he is unique.

8. Social Psychology: Man as a social being is both an individual and a member of group. (P14).

In Pakistan the official use of the term "social studies" is not very old. It appeared for the first time in 1951 in the revised syllabi prescribed by the Department of Education of the West Punjab Government for the primary and middle classes. It replaced the long used term "general knowledge". And currently in Pakistan this subject is taught under the title of "social studies" from grade one to eight, and "Pakistan studies" in lower and higher secondary classes. For the purpose of this research study the terms "Social studies" and "Pakistan studies" are used synonymously. Commission on National Education (Govt. of Pakistan, 1959) stressed three main components for effective program of teacher education i.e. proper selection of suitable prospective teachers; adequate pre-service training; and sound in-service educational and professional growth. The purpose of teacher education is to develop teachers personally and professionally. National Curriculum of social studies (Govt. of Pakistan, 2002) stated that social studies teachers should know how to deal with the concepts of curriculum with reference to the competencies developed in different areas of knowledge. They should encourage the students to discuss real life situations and build their capabilities to solve day to day problems by applying their knowledge. 
According to Singh (2004), a social studies teacher must attend a full course of professional training for knowing effective methods of teaching, audio-visual aids, and child psychology. He further described that methods of teaching give training in constructive thinking, reasoning, and critical judgment. Therefore, methods of teaching expose students to knowledge and experiences that are helpful in the development of understanding, critical thinking, practical skills, and interests. Present study is an attempt to analyze current situation in teaching and learning of social studies.

\subsection{Focus of Study}

Keeping in view the importance of Social studies in the school subjects, this study was undertaken to find out the current situation of Social Studies teaching and learning in the Girls Secondary school of Lahore city.

\section{Methodology}

The study was conducted to compare the ideas held by the teachers and students of $9^{\text {th }}$ and $10^{\text {th }}$ class on the current practices in the social studies class rooms.

Structured interview schedules for teachers and students were prepared to solicit the information from teachers and students...Thirty Teachers and hundred Students (three teachers and ten students from each school) were randomly selected from ten conveniently selected government schools of Lahore district. Teachers and Students were fully taken into confidence on maintenance of confidentiality of the information collected from them. The researchers specially developed good rapport with the students to make them feel comfortable before taking the interview. They spent one period of 30-40 minutes in all the schools before taking the interviews. During this class they tried to be as friendlier as possible and discussed general issues and problems in the society with them. Students were actively engaged in the discussion process so that they should feel comfortable when they were interviewed. In this way students freely respond on all the questions without any fear of their teacher. Further, Students' interviews were taken in the absence of their teachers. The detail of interview schedule is given below:

i. $\quad 08$ questions with some connected questions were asked from 30 teachers.

ii. $\quad 08$ questions with some connected questions were asked from 100 students.

iii. The questions were asked in the same sequence to all students and teachers.

iv. Teachers and students were taken from $9^{\text {th }}$ and $10^{\text {th }}$ class.

v. The physical conditions were nearly the same for each subject of study during interview.

In following lines main themes are given in a sequential manner:

i. Liking about the subject of social studies.

ii. Teaching methodology and use of additional teaching material .... what type of additional material

iii. Difficult content areas in social studies and Refresher courses attended by the teachers...standard of such courses.

iv. Parent's attitude toward students' performance.

v. Selective study by the students on the subject.

vi. Lesson planning by the teacher.

vii. Steps taken by the teacher for the betterment of teaching of social studies.

viii. Assessment criteria.

\section{Results and Discussion}

The data were analyzed and the following results were drawn from the study:

\subsection{Profile of respondents}

Demographics and profile of respondents of the study are given in tables 1 and 2:

According to the results, it can be seen that teachers with bachelor's degree are giving relatively better results than masters degree holders. It was also discovered that teachers with more than twenty years experience were showing $100 \%$ results. Teachers, below twenty years of experience were showing good results too.

\subsection{Liking of the subject}

In terms of liking the subject $72 \%$ students don't like this subject. When they were asked the reasons for this situation, most of the students complain that their teachers are so boring therefore, the subject is also boring. 
When this question was asked by the teachers $78 \%$ teachers said that they like to teach this subject (see figure 1). This was a reverse situation.

One of the students reflected in these words:

“... I am a position holder in this class. I always got good marks in all the subjects. Mostly my marks are above $80 \%$. But I am a bit weak in the subject of social studies. It is always difficult to memorize the boring information given in this subject. Our teacher is very polite and students like her for her good behavior in the class but it is perhaps the way we memorize the information. None of my teachers in the previous classes from class one to eight, tried go beyond the bookish information."

\subsection{Strategies used to increase the effectiveness of lesson}

The teachers and students were inquired about the Strategies they use to increase the effectiveness of lesson (See table 3 and 4). Information was sought on four point's i.e. oral explanation of information given in the text, relate information with previous knowledge of students, and relate lesson to the current events, use of A.V. aids i.e. maps, globes, charts, models.

It is very interesting to know that $100 \%$ teachers were of the view that they give oral explanation of information given within the text book of social studies. While more than fifty percent students contradict this statement. Similar contradiction could also be seen in the other statements i.e. $93 \%$ teachers related information with the previous knowledge, $80 \%$ teachers relate lesson to the current information and $100 \%$ teachers use A.V. aids to increase the effectiveness of the lesson but majority of the students reject their claims and they gave opposite opinion. Some extreme illustrations from the interviews conducted from the students are given below in their own words:

Student No. 51 reported that "We have no interest in this subject...infact it is very boring to attend this class...our teacher comes to class and start reading from the book or she ask the students to read the lesson aloud turn by turn..."

Student No. 21 said that "My teacher is very strict. We could not comprehend many things in this subject like I am very poor in geographical features, import and export of goods etc etc...."

Student No. 84 was of the opinion that "her teacher doesn't like those students who ask questions. She harshly responds to those students....."

\subsection{Teachers' and students' opinions on difficult content areas}

Teachers and students were asked about the difficult content areas in the subject of social studies/Pakistan studies i.e. history, geography, political science, and economics. They responded from most difficult to least difficult subject area. Table 5 and 6 presents the results:

Results show that teachers find the areas of geography as the most difficult content area with the percentage of 57 while economics was the second as $30 \%$ teachers said that they feel difficulty in teaching these concepts. As far as the students' opinion is concerned majority of the students were of the opinion that geography is the hardest area to study while $21 \%$ students thought that they feel difficulty in understanding the concepts of history.

Along with this information teachers were asked in the interview that if they are finding something difficult to teach then how many times they were offered refresher courses or training programs to overcome their deficiency? Hundred percent teachers respond that they have never gone to attend any refresher course. As in most of the cases the teachers said such things in their interviews which show their deficiency in using maps and globes:

$$
\begin{aligned}
& \text { "I can not read maps myself...." } \\
& \text { "It is difficult to tell students about maps and globes....." } \\
& \text { "We have globes and maps in the school but we don't use...." } \\
& \text { "It makes no difference as students never ask about such information". }
\end{aligned}
$$

\subsection{Parent's attitude}

The parents do not care to visit school to interact with the teachers and know about their daughters results $(65 \%$ teachers) while $35 \%$ teachers reported that parents do come to check the progress of their daughters in all subject (see figure 2). 


\subsection{Opinion on selective study by the students}

It was interesting to know that $100 \%$ teachers said that they teach full course material but students study only few selected lessons which they thought are important in the text book. While students were opposing this view as $80 \%$ students told that their teachers do not cover full course and they teach them selected lessons or selected topics from the book. This contradiction raises many questions for teachers and school administrators.

One of the students expressed his views in the following words:

"I think teachers left some unimportant topics that are easy enough for students to study themselves. They said to cover some chapters by ourselves which are included in the exams. In previous classes some teachers do cover the course by giving some chapters for self study in the summer vacation"

\subsection{Lesson Planning}

Eighty percent teachers respond that they always prepare their lessons before going to teach different sections of social studies. But it was interesting to identify that not even a single teacher was able to show the lesson plan and they gave many excuses for not having lesson plans with them. Examples of teacher no 05 and 27 are quoted below:

\section{"I don't think that I need written lesson planning everyday. I know what I have to teach...." (Teacher no 05) \\ "I use to plan my lessons but I can manage it in my mind, so I think it is not useful to write it every day..." (Teacher no 27)}

\subsection{Steps taken by the teacher for better teaching}

All teachers $(100 \%)$ respond that they give full attention to their teaching and they use to consult with seniors and try to read other related material as well. This is again contradictory to the students' responses on previous question i.e. contradictory statements of teachers and students on four strategies used by the teachers to make their lessons effective.

\subsection{Assessment Criteria}

All the teachers were of the opinion that they use to test students according to the pattern given by the board of intermediate and secondary education, Lahore. They told that this strategy help students to get good marks in the board examination. So no other techniques are considered to be important in teaching of social/Pakistan studies i.e. project method, critical analysis of issues and evaluation, social surveys, observations etc. It was noted that teachers were only concerned with good results because results of students' annual examinations contribute in the teachers' upward mobility in their job. Students' results also reported in their annual ACRs.

In this way, this study shows the current practices adopted by the social studies teachers in secondary schools of Lahore city. There is a need to seriously think about the present situation as social study is a very important subject that covers important social, cultural, historical, political, psychological, geographical and economical aspects of our living. Therefore teachers and students should be seriously engaged in variety of experiences and activities in the subject of social studies to raise the interest level of students. That's the only way to promote civic competence among prospective citizens. School administrators should take certain measures to facilitate and guide teachers to overcome their deficiencies with good supervision, provision of facilities, encouragement, timely feedback to teachers and direct and regular interaction with students on reported areas of concern. Teachers should also be provided opportunities to participate refresher courses at school level to polish their skills.

\section{References}

Aggarwal, J.C. (1983). Teaching of social studies. A practical approach. new Delhi: Vikas Publishing house LTD.

Arends, R. I. (2004). Learning to teach, $\left(6^{\text {th }}\right.$ edition). New York: McGraw-Hill Companies Inc.

Barth, J. L. (1980). Principles of social studies. America, University press of America.

Blair, T. R. (1988). Emerging Patterns of Teaching: from methods to field experiences. Columbus: Merrill Publishing Company.

Cullingford, C. (1995). The Effective Teacher. New York: Cassell.

Dahama, O.P. and Bhatnagar, O.P. (1997). Education and communication for development. New Delhi: Oxford and IBH Publishing Co.s 
Forrester, J.D. (1979). Teaching of social studies. New York: The Macmillan Publications.

Govt. of Pakistan. (1959). Report of the commission on national education. Karachi: Ministry of education. Manager of publications.

Govt. of Pakistan. (2002). National Curriculum of Social Studies. Islamabad: Ministry of Education.

Michaels, J. U. (1979). Social studies for children in democracy, $6^{\text {th }}$ edition. New Jersey: Prentice Hall.

National Council for the Social studies. (1994). Curriculum standards for social studies: expectations of Excellence. Washington DC.

Panda, B.N. and Tewari A.D. (1997). Teacher Education. New Delhi: A.P.H. Publishing Corporation.

Singh, Y.K. (2004). Teaching of Social Studies. New Delhi: APH Publishing Co.

Table 1. Qualification of teacher and average board result in social study 2006

\begin{tabular}{|l|l|}
\hline Qualification & Average board result 2006 \\
\hline Bachelors degree holder & $93 \%$ \\
\hline Masters degree holder & $85 \%$ \\
\hline
\end{tabular}

Table 2. Experience of teacher and average board result in social study 2006

\begin{tabular}{|l|l|l|}
\hline Experience & N & Average board result 2006 \\
\hline $1-10$ & 13 & $80 \%$ \\
\hline $11-20$ & 09 & $82 \%$ \\
\hline Above 20 & 08 & $100 \%$ \\
\hline
\end{tabular}

Table 3. Strategies adopted by teachers to increase the effectiveness of lesson $(\mathrm{N}=30)$

\begin{tabular}{|l|l|l|l|l|l|l|l|l|}
\hline $\begin{array}{l}\text { Responses of } \\
\text { teachers }\end{array}$ & $\begin{array}{l}\text { Oral explanation of } \\
\text { information given in } \\
\text { text book }\end{array}$ & $\begin{array}{l}\text { Relate information } \\
\text { with previous } \\
\text { knowledge of } \\
\text { students }\end{array}$ & \multicolumn{2}{l}{$\begin{array}{l}\text { Relate lesson to the } \\
\text { current events }\end{array}$} & $\begin{array}{l}\text { Use of A.V. aids } \\
\text { i.e. maps, globes, } \\
\text { charts, models etc. }\end{array}$ \\
\cline { 2 - 10 } & N & $\%$ & N & $\%$ & N & $\%$ & N & $\%$ \\
\hline YES & 30 & 100 & 28 & 93 & 24 & 80 & 30 & 100 \\
\hline NO & - & - & 02 & 07 & 06 & 20 & - & - \\
\hline
\end{tabular}

Table 4. Students opinion on strategies used by the teachers $(\mathrm{N}=100)$

\begin{tabular}{|l|l|l|l|l|l|l|l|l|}
\hline \multirow{2}{*}{$\begin{array}{l}\text { Responses of } \\
\text { teachers }\end{array}$} & \multicolumn{2}{l}{$\begin{array}{l}\text { Oral explanation of } \\
\text { information given in } \\
\text { text book }\end{array}$} & $\begin{array}{l}\text { Relate information } \\
\text { with previous } \\
\text { knowledge of } \\
\text { students }\end{array}$ & \multicolumn{2}{l|}{$\begin{array}{l}\text { Relate lesson to the } \\
\text { current events }\end{array}$} & $\begin{array}{l}\text { Use of A.V. aids } \\
\text { i.e. maps, globes, } \\
\text { charts, models etc. }\end{array}$ \\
\cline { 2 - 10 } & $\mathrm{N}$ & $\%$ & $\mathrm{~N}$ & $\%$ & $\mathrm{~N}$ & $\%$ & $\mathrm{~N}$ & $\%$ \\
\hline YES & 40 & 40 & 08 & 08 & 17 & 17 & 26 & 26 \\
\hline NO & 60 & 60 & 92 & 92 & 83 & 83 & 74 & 74 \\
\hline
\end{tabular}


Table 5. Difficult content areas of social studies according to teachers $(\mathrm{N}=30)$

\begin{tabular}{|l|l|l|}
\hline \multirow{2}{*}{ Content areas } & Responses \\
\cline { 2 - 3 } & $\mathrm{N}$ & $\%$ \\
\hline History & 03 & 10 \\
\hline Geography & 17 & 57 \\
\hline Political Science & 01 & 03 \\
\hline Economics & 09 & 30 \\
\hline
\end{tabular}

Table 6. Difficulty felt by students to learn the content areas of Pakistan studies $(\mathrm{N}=100)$

\begin{tabular}{|l|l|l|}
\hline \multirow{2}{*}{ Content areas } & Responses \\
\cline { 2 - 3 } & $\mathrm{N}$ & $\%$ \\
\hline History & 12 & 21 \\
\hline Geography & 77 & 77 \\
\hline Political Science & 05 & 05 \\
\hline Economics & 06 & 06 \\
\hline
\end{tabular}

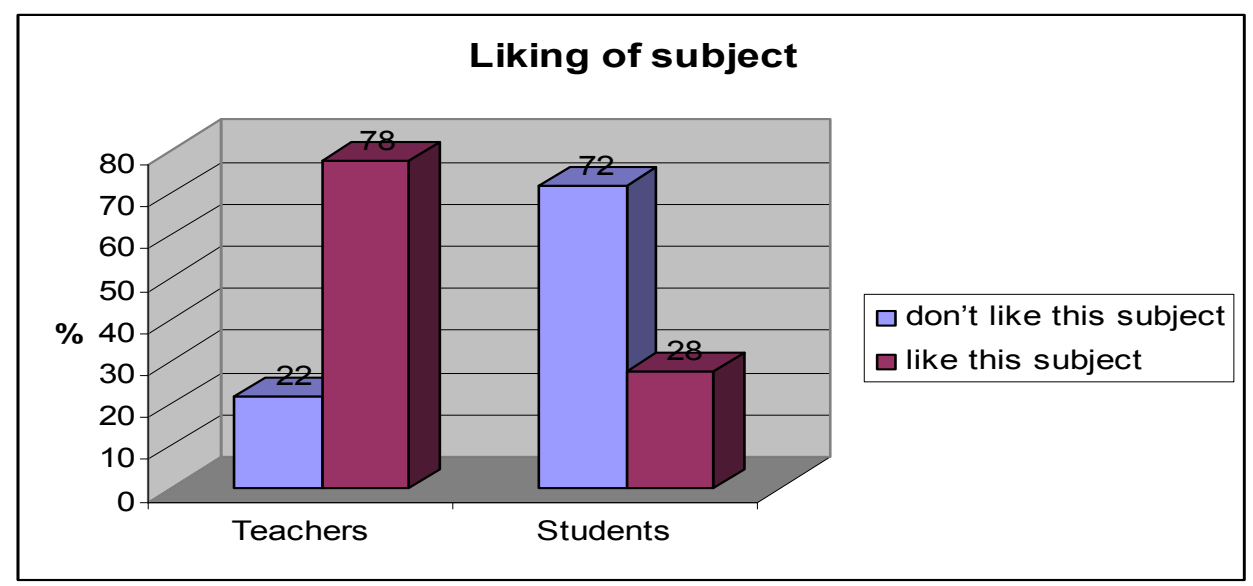

Figure 1. Liking of the subject by the teachers and students

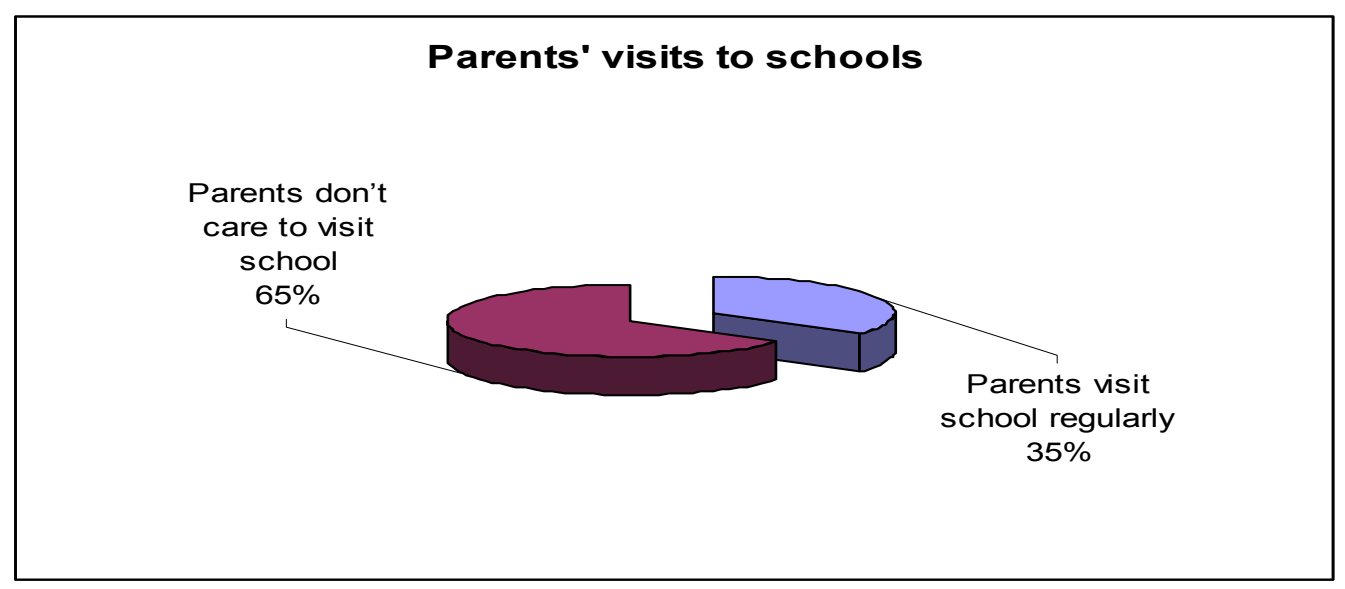

Figure 2. Parents` visit to schools 